\title{
Transatlantica
}

Revue d'études américaines. American Studies Journal

\section{From Commons to Capital: The Creative Destruction of Coastal Real Estate, Environments, and Communities in the US South}

Andrew W. Kahrl

(2) OpenEdition

Journals

Electronic version

URL: https://journals.openedition.org/transatlantica/16278

DOI: 10.4000/transatlantica. 16278

ISSN: 1765-2766

Publisher

Association française d'Etudes Américaines (AFEA)

Electronic reference

Andrew W. Kahrl, "From Commons to Capital: The Creative Destruction of Coastal Real Estate,

Environments, and Communities in the US South", Transatlantica [Online], 2 | 2020, Online since 01

February 2021, connection on 02 February 2023. URL: http://journals.openedition.org/transatlantica/ 16278 ; DOI: https://doi.org/10.4000/transatlantica.16278

This text was automatically generated on 2 February 2023

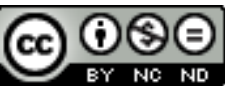

Creative Commons - Attribution-NonCommercial-NoDerivatives 4.0 International - CC BY-NC-ND 4.0 https://creativecommons.org/licenses/by-nc-nd/4.0/ 


\title{
From Commons to Capital: The Creative Destruction of Coastal Real Estate, Environments, and Communities in the US South
}

\author{
Andrew W. Kahrl
}

“The rich people are going to destroy this Earth.
It's just a matter of time."
Daufuskie Island resident, 1992 (Hollyday 18)

1 On a December morning in 1988, postmaster Henrietta Canty arrived at her tiny office on Daufuskie Island, South Carolina, and began slipping into p.o. boxes the letters that would spell her community's demise. The previous year, Beaufort County had conducted a mass re-appraisal of property assessments and was now issuing updated tax assessments to property owners. Bertha Stafford opened hers to discover a tax increase of over 600 percent. Ella Mae Stevens's tiny home on a one-acre lot, previously valued at $\$ 11,000$, was now deemed to be worth nearly $\$ 100,000$. Geneva Wiley's acreage was now being assessed at over $\$ 112,000$, up from $\$ 10,000$ a few years before. A disabled widow without medical care, who sold homemade crab cakes to tourists to make ends meet, saw the assessed value of her land nearly quadruple (Korotkin, 1989).

2 The county's new property assessments served to announce capitalism's arrival on this, one of the last remaining undeveloped Sea Islands on the South Carolina coast, and hasten the demise of an independent Black landowning community on Daufuskie Island. Families with little source of income, whose only significant asset was their land, would have mere weeks to round up enough cash to pay an exorbitant tax bill or fall into tax delinquency and have the property sold at the county's annual tax auction later that fall. Some rushed to put portions of their land up for sale, in the hope that sacrificing some would allow them to save the rest; others skimped on food and medicine; still others stuffed the bill away and tried to ignore its ominous warnings. Speculative investors made that impossible. In the coming weeks and months, they 
descended on the island, knocking on doors, handing out business cards, offering the desperate and the confused a quick and tidy resolution to their predicament. Six months later, those who had failed to settle their tax debts would have their property sold to one of the dozens of investors who crowded into the county courthouse on the first Monday in October to bid on tax delinquent property, and they would be left with nothing.

3 This was a scenario that played out-and continues to play out-in gentrifying real estate markets across the US. The "discovery" of an undervalued and underdeveloped real estate market sparks a frenzy of speculative investing, as buyers seek to acquire land and homes from unwary owners at below-market values. Once the development cycle is set in motion, and powered by the administrative powers of the local state, it becomes seemingly impossible to arrest. Real estate development and the infrastructure and land use redesignations that made it possible in one area sets the stage for future development in surrounding areas, in part, by triggering sharp spikes in property assessments and landowners' tax obligations. Property owners in the path of development are forced to pony up more taxes-which, for many on fixed incomes, is impossible-or get out of the way, which is what the speculators, developers, and growth-minded local officials who stood to profit from their departure had hoped, and expected, all along.

4 A potent mixture of greed, racism, poverty, and political disfranchisement fueled cycles of development and displacement that resulted in massive Black land losses and neighborhood erasures across rural and urban America in the twentieth century. In coastal real estate markets, Black land-taking was inextricably tied to state-subsidized and -administered forms of environmental exploitation and ecological devastation. ${ }^{1}$ Coastal capitalism, as I describe in my 2012 book The Land Was Ours, entails the simultaneous-and interrelated-process of commodification, privatization, physical stabilization, and marketing of coastal real estate and its unique-and uniquely fragile and unstable-environmental features for private development (Kahrl, 2016; 2014). It bears many of the same features of real estate capitalism in general and, like urban gentrification, depends on active collaboration and support from various actors within what Samuel Stein describes as the "real estate state" to clear spaces and generate new opportunities for profit. Unlike urban gentrification, though, coastal capitalism does not simply generate profits through acquisition and state-supported enhancement of undervalued spaces. Rather, it works with various agents of the state-from the US Army Corps of Engineers to state courts down to county tax assessors-to turn public commons into private property, give a sense of permanency and stability (essential to capital investment) to highly volatile and environmentally sensitive shorelines, and align public policies (such as flood insurance and disaster relief) to not only mitigate losses, but, more critically, ensure an endless cycle of re-investment and redevelopment. Like real estate capitalism and urban gentrification, coastal capitalism also entails cultural transformation, commodification, and erasure-of the people and communities that occupied the spaces it seeks to envelop, and of the ways of living and human relationships to the land that preceded its arrival.

Because African Americans lived along and claimed ownership over vast portions of the coastal South at the time coastal capitalists descended onto southern shores in the decades following World War II, the commodification and managed enhancement of coastal property-indeed, the process of turning commons into property-was, in the 
US South, an inherently racialized process, one in which capitalist actors exploited existing racial inequities and power dynamics for profit. $^{2}$ On Daufuskie, the destruction of native Blacks' culture and the violence inflicted on people and the land served coastal capitalists' larger objectives of a compliant, dependent Black labor force and robust real estate market.

6 For the coastal capitalists who descended onto Daufuskie Island in the 1980s, the property assessment and consequences for nonpayment functioned as an agent of market expansion and instrument of economic plunder and subordination. ${ }^{3}$ Because South Carolina, like many other states, mandated that assessments be based on market value, as opposed to current use, property assessments in high-poverty, low-income areas targeted for development became a self-fulfilling prophecy, forcing land onto the market and ensuring that its most profitable use would be realized (Thomas, 1977 115; Thomas, 1978 275). And because South Carolina allowed for the sale of an entire parcel for a single unpaid tax bill, tax delinquency sales became the site for a lucrative, and government-administered, form of predatory investing. Combined, local tax laws helped to nurture a "new plantation" economy that relied on the availability of cheap land and a cheap, disposable, and desperate labor force stripped of alternatives, and stripped of their land.

7 Much of the land being turned into golf courses and resorts beginning in the 1960s had been first acquired by freed slaves during the Civil War and Reconstruction (Rose; Williamson). The Sea Islands became the literal and spiritual birthplace of freedpeople's struggle for landed autonomy following emancipation, and, for a century after the Civil War, it remained home to the largest concentration of Black-owned land in the United States. From the 1870s through the 1940s, Beaufort County had one of the largest percentages of Black residents, and largest percentage of Black-owned land, of any in the nation (Foner 108; Slaughter 87). That began to change, dramatically, following the development of the Sea Pines Plantation resort on Hilton Head Island in the 1950s, which sparked a frenzy of land speculation on this and neighboring islands and placed African American landowners in the cross-hairs of a growth industry hungry for the very lands Black people had, over a half-century earlier, flocked to when seeking shelter from Jim Crow. ${ }^{4}$

8 State lawmakers and the courts cleared a path for coastal capitalists by expanding opportunities for Black land dispossession. In disputes over "heirs properties"-the legal term for lands lacking clear title and owned collectively by the original owner's descendants in the form of undivided shares, a common condition for Black-owned land across the rural South-probate judges increasingly ordered partition sales. This allowed land speculators to snatch land out from under the feet of its occupants simply by purchasing a share from a family member and then petitioning the court for a sale, whereupon the investor easily outbid the owners. ${ }^{5}$ In 1975 , lawmakers amended the state's tax code to require localities to assess property at its market value, while establishing different rates of taxation for different types of property, with commercial properties taxed at the highest rate and agricultural lands at the lowest. In areas lacking clear zoning codes, the onus was on the owner to apply for his or her property to be classified as agricultural. Otherwise, the assessor was free to tax the land according to its potential value as opposed to its current use. What this meant was that in areas experiencing-or even anticipating-real estate development, unclassified and undeveloped rural land could be taxed as if it was a luxurious seaside home or gated 
subdivision. These reforms would ultimately provide local governments legal cover for carrying out confiscatory tax policies (US Department of Agriculture 117-118; Thomas, 1976 45-47). And, finally, growth-oriented state officials across the ideological spectrum stacked the state's new coastal regulatory agency with people tied to the coastal real estate industry, while lobbying federal regulators and lawmakers to subsidize the infrastructure and insurance that made development on fragile barrier islands possible and profitable.

In the late 1970s, Daufuskie Island still remained on the margins of the new plantation economy enveloping Hilton Head and neighboring islands-and for good reasons. Its distance from the mainland and neighboring islands precluded any capitalist visions of a bridge or causeway easing the path of development. Instead, the island remained accessible only by boat, limiting contact between the island's poor but resourceful and fiercely independent Black community and the mainland. Aside from an elementary school, church, and general store, it remained free of development, and with few exceptions, free of white people, period. African Americans claimed ownership of roughly half of Daufuskie Island's total acreage; the rest belonged to absentee white landowners, who occasionally used it for hunting expeditions. But much of the island, including the white-owned lands and all of its shoreline, functionally served as a commons. Black families' cattle and hogs roamed and grazed freely, islanders fished its shores and hunted its wildlife without restrictions. The only fences on the island served to protect small garden plots from foraging animals (Ceruti; Anderson; MoutoussamyAshe; Slaughter; Hollyday). Legally, the foreshore was public land. The common law Public Trust Doctrine placed beaches in the hands of states to protect from attempts to develop and privatize, and ensure public access (Sax; Brower et al.; Kaufman and Pilkey 232; Archer et al.).

10 Then, in 1980, a consortium of investors led by Hilton Head developer Charles Cauthen purchased 2,331 acres (the white-owned half of the island) for \$4.5 million, and in 1982 announced plans to market the land for development (Dougherty). Their goal was to build an exclusive seaside resort with an 18-hole PGA golf course, affording guests an array of modern luxuries behind the plantation gates while maintaining the island's rustic character. Cars were to be banned. Nature, or rather a manicured version of it, was to be in abundance.

11 In the years following Hilton Head's "discovery" in the 1950s, Beaufort County government became an accessory to the coastal real estate industry, acting as both a promoter and facilitator of the region's transformation from a rural agricultural to a leisure and tourism economy, and from predominantly black and poor to increasingly white and prosperous population. To that end, the Beaufort County assessors' office had, in the years prior to this massive land acquisition, enacted sharp increases in land valuations on areas of Daufuskie Island targeted for development; some families saw their tax bills quadruple in one year. This proved to be a sign of things to come.

12 First, though, Daufuskie's would-be developers needed to ensure the barrier island's eligibility for the federal subsidizes and support that made large-scale real estate development on flood- and storm-prone coastlines possible. It needed the National Flood Insurance Program, which provided federally subsidized flood insurance to properties in coastal areas; the Army Corps of Engineers, which armored coastlines and protected coastal properties; and Congress, which earmarked funds for infrastructure and other improvements that made these places habitable. Federal dollars fueled the 
rise of coastal capitalism in postwar America and, in the wake of damaging storms, ensured its recovery and subsequent resurgence. Nowhere was this more evident than along barrier islands. These thin, highly mobile slivers of land serve as the first line of protection against the furies of the sea. In their natural state, barrier islands are in constant movement, eroding in some areas, building up in others, forming new inlets and closing old ones, with each passing season. During a major storm, the topography of a barrier island and the shape of its shoreline can change dramatically. Attempts to stabilize and hold in place these highly flexible land masses are not only futile, but endanger areas further inland, by removing the natural vegetation that absorbs a storm surge. In short, barrier islands are manifestly unsuited for development. But developed they were. Some of the most heavily developed areas, and most valuable real estate, along the Atlantic coast were on barrier islands: places such as Atlantic City, $\mathrm{NJ}$, Ocean City, MD, Miami Beach, FL, all of which were in constant battle with the forces of nature, and at great cost. One estimate found that, by the late 1970s, federal agencies spent over \$166 million each year to protect and maintain barrier island properties (US House of Representatives 27394). ${ }^{6}$

One of the hallmarks of coastal capitalism was its ability to externalize its devastatingand unrelenting-costs. But by the early 1980s, a growing chorus of critics were calling on Congress to protect barrier islands from further development by cutting off the forms of federal aid that had fueled their growth. The 1982 Coastal Barriers Resources Act aimed to do just that. The bill made undeveloped barrier islands ineligible for federally subsidized flood insurance and infrastructure support. It didn't enact an outright ban on development, but it might as well have. In South Carolina, the ending of federal subsidies for barrier islands threatened to effectively kill plans to develop exclusive "plantation" resorts on Daufuskie Island. That was until South Carolina Senator Strom Thurmond succeeded in having Daufuskie Island removed from the list of undeveloped barrier islands covered under the Act (US Senate 2883). ${ }^{7}$

With federal support ensured, plans to transform Daufuskie into a playground for wealthy whites resumed. In 1984, the land development division of the global conglomerate International Paper Company purchased 1,000 acres from the land trust that had acquired one-half of the island two years before and began work on what would become the Haig Point plantation resort. A multi-stage, state-administered process of forced removal and dispossession ensued (B.M. Smith).

15 First came enclosure and destruction of the commons. The Melrose Company, the firm behind one of the island's two major gated community developments, fenced and cleared 400 acres of forest land for construction of a golf course to be designed by golfing legend Jack Nicklaus. This eliminated much of the land that islanders' cattle and hogs used for grazing and foraging, while cutting off access to areas used for fishing and hunting. Next, it secured the approval of the state's Coastal Council (of which Melrose's CEO and attorney were both members) to close off access to public roads leading to the shore, thereby preventing islanders from enjoying access to places where they had fished and harvested shellfish for generations.

Destruction of a way of life and destruction of the environment went hand in hand. Behind these newly built fences, developers leveled natural storm barriers, stripped the land of trees and vegetation, and stripped its inhabitants of their dignity and ancestry. In what amounted to an act of "cultural genocide," as attorneys for the NAACP Legal Defense Fund later charged, the Melrose Company built a real estate office and 
welcome center on top of a cemetery; during the construction, work crews (which included native Black Daufuskians hired as day laborers) dumped the bones of islanders' ancestors into the Cooper River, where they washed out to sea (Hollyday; Korotkin, 1990a; Cass).

Writing on Appalachia, the historian Steven Stoll characterized land enclosure as a process that "severed labor from the land and made both available for other uses." It "transformed people who had always decided when or whether to sell the things they made into wageworkers whose every motion created a commodity for their employers to sell" (58). Thus it was on the Sea Islands, as well. Enclosure turned islanders' economic poverty (one that had formerly been offset by the richness of their ecological base) into a critical liability, cutting off access to resources that provided both subsistence and commodities for exchange.

Because state law mandated that land be assessed at its market value, enclosure and development of one part of the island precipitated dramatic increases in property taxes -the very thing that those exchanged commodities had formerly been able to satisfyacross the entire island. Following a countywide reassessment in 1988, property taxes on Daufuskie Island increased by as much as 700 percent. Residents who had previously paid less than $\$ 20$ a year in property taxes received $\$ 130$ bills; families that had previously paid $\$ 130$ annually were forced to shoulder a $\$ 2,800$ annual tax bill (S. Ross).

Basing property assessments on speculative values served the interests of coastal capitalists in two ways. A single tax increase promised to not only open up more land for development, by weakening native islanders' ability and resolve to hold onto the land; it also forced more native islanders to seek employment and thereby increased the pool of cheap labor upon which the new plantation economy relied. Indeed, the mere acquisition of a part of the island was enough to put the wheels in motion toward eventual acquisition of the remainder. Better still for the developers, if not the victims, the island's transformation from commons to capital, and its population from poor and Black to affluent and white could be carried out without recourse to more crude forms of violence, intimidation, and blatant illegality that had characterized other campaigns of Black land-taking and labor subjugation. It could be bloodless, by-the-books, ostensibly color-blind, and, when coupled with the promise of new jobs (no matter how low the wages), even garner some support from Black residents.

Despite their claims to impartiality and objectivity, tax assessors played an active role in shaping markets in the interests of large developers and wealthy landowners. ${ }^{8}$ On Daufuskie Island, the 1988 reassessment resulted in wide variations in effective tax rates. These new assessments, as attorneys and investigators representing Black landowners later found, tended to reflect and, in practice, advance coastal capitalists' vision of the island's future demographics, with white- and corporate-owned land receiving artificially low and extremely generous assessments in comparison to Blackowned land. ${ }^{9}$ For example, a wealthy white retiree who sailed and traveled full time was taxed $\$ 395$ on his 10 -acre lot, which included a house. Across the island, an elderly Black woman was forced to pay $\$ 674$ on her modest home and 6 acres of woodland. A retired white paper mill executive received a $\$ 171$ tax bill on his waterfront home and 8 acres of waterfront property. Meanwhile, an African American widow was taxed $\$ 443$ for her 2-acre tract (Morris). 

landowners into tax delinquency. County officials aggressively pursued cases of tax delinquency and ruthlessly exploited the state law that allowed it to sell an entire tract of land for a single unpaid tax bill, no matter how large the property or how small the debt. ${ }^{10}$ This, in turn, created a lucrative market in tax liens. Investors clamored for the opportunity to acquire valuable real estate for pennies on the dollar. Between 1986 and 1991, the number of properties sold at the county's annual tax auction tripled (“Opinion Split").

Beginning in the 1970s, the Penn Center, a renown civil rights and cultural institution located on St. Helena Island, launched a series of programs and initiatives aimed at stemming the tide of Black land loss on the Sea Islands. It established a Black Land Services program, which, under director Joe McDommick, fought tirelessly to protect and assist African Americans in danger of losing their property at tax sales. ${ }^{11}$ They held legal clinics, helped families to complete applications for tax exemptions, contacted tax delinquent property owners before their land went to auction, and, with what little resources they could muster, attempted to settle as many families' tax debts as they could. McDommick even tried to appeal to land speculators' conscience-a tall orderby attending the county's annual tax auction and speaking to the assembled bidders of the problems Black landowners were facing and asking that they refrain from bidding on certain properties (McDommick; Hansen 143-161; Grabbatin 93-98). of structural and institutional forces aligned against them. For one, the state's tax delinquency laws not only imposed the most extreme penalty for failure to pay (total loss of land, no matter how large the holdings or how small the debt), it also made it extremely cost prohibitive for delinquent taxpayers to settle their debts. In addition to a host of penalties, fees, and interest added on to the original tax debt, counties required a property owner to prepay their property taxes for the coming year in order to satisfy a tax lien (Rivers, 2006). For families living well below the poverty line, such requirements practically guaranteed that, once tax delinquent, their property was as good as gone.

Coupled with a tax code designed to punish and exploit the poor were the discretionary powers local tax administrators enjoyed. The state granted local assessors a wide degree of latitude in determining market values and approving (or denying) tax exemptions. In practice, this allowed for large-scale developers and wealthy homeowners to receive generous tax breaks in the form of agricultural exemptions for land undeserving of such protection, while at the same time denying such benefits to poorer landowners on the narrowest of technicalities. As coastal capitalists descended on the Sea Islands beginning in the 1970s, Black Land Services scrambled to help farming families apply for this exemption, which could significantly lower their tax bills. But for landowners in areas in the path of future development, these applications were routinely denied for what county officials claimed was insufficient evidence or subsequently revoked, often at the behest of land speculators who made a habit of reporting exempted land not being farmed to county officials (Morris; Korotkin, 1990a; J. Smith).

Henrietta Canty had devoted much of her career to exposing and fighting less visible forms of racial discrimination. Prior to her arrival on Daufuskie as postmaster in 1988, Canty had spearheaded in 1971 a successful class-action lawsuit against the federal

Transatlantica, 2 | 2020 
government over pay discrimination at the Office of Economic Opportunity and had fought against discriminatory zoning ordinances, school district gerrymandering, and automobile insurance redlining as a local activist and later a member of the Georgia State Assembly from Southwest Atlanta. And she was under no illusions as to the Melrose Company's intentions and Beaufort County's complicity. "I've known the people of this island for more than 20 years," she told a reporter for the Washington Post, "and I know the games-all the fancy developer games. Once the building starts the lands gets more valuable and taxes go up and there's talk of fire districts and auto licensing and more taxes and-well-the people just never get a chance" (Yeadon). Once installed as postmaster, Canty began denouncing the new assessments-the overvaluation of Black homes, and the under-valuation, through fraudulent agricultural exemptions, of white-owned property-as a form of "covert racism" meant to hasten Blacks' exodus from the Sea Islands. She actively worked to draw national attention to the issue, soliciting the support and assistance of civil rights and legal defense organizations (Canty, 1988; Yeadon; Hollyday 16; S. Ross; Korotkin, 1990c).

Public officials dismissed Canty's charges and expressed indifference over the predation of tax delinquent property owners by speculative investors. "That's just the way it goes," a spokesperson for the state's tax commission said of the mounting crisis of Black land loss. "If someone can't afford to own property because they cannot pay taxes, then they shouldn't own the property," county councilman Bill Bowen remarked. On the charge of intentionally over-assessing Black-owned land, Beaufort County tax assessor Leslie Smith pled "color-blind" innocence. "Each property is taken on its own individual merits" ("Developers Sued"; Morris).

But it wasn't just taxes that were forcing African Americans off the island, nor was it only land that the corporate resorts were after. The new plantations relied on large numbers of workers to prepare the meals, tend the grounds, clean the rooms, and perform other forms of menial labor, and do so at low wages and on an erratic, seasonal basis. Ultimately, each stage of coastal capitalist expansion and consolidation cleared the path toward the next. Land enclosure and decimation of native species' habitats by developers destroyed Black islanders' makeshift economy and inflicted grievous wounds on families' and individuals' sense of self-worth and ability to function as a collective. For developers, taking Blacks' land was merely a transitory step toward African Americans' reincorporation into the new plantation economy as cheap and unorganized labor-bereft of land, resources, options, or political standing and influence. In this respect, developers' accumulation of Black land and enclosure of the islands' commons functioned as a form of literal dispossession-property taking-and figurative dispossession, of the will and means of collective action. More so than the land itself, the process of Black land dispossession-the disempowerment it entailed and divisions it engendered within the Black community-would prove crucial to the realization of corporate visions of a manufactured paradise consisting of deep-pocketed white vacationers tended to by a docile, dark-skinned servant class.

But corporate officers and county officials were not content to simply wait it out. The same month the county sent out reassessment notices to property owners, it also ended regular ferry service to Daufuskie, drastically scaling back the only means of public transportation to and from the island. Henceforth, the county only provided a single trip to the mainland at 6:30 am each weekday, and a single trip back to the island at 4:30 pm each weekday. It ended weekend service entirely. This not only imposed a 
heavy burden on families (turning a single trip to a supermarket into an all-day affair), it also severely constrained islanders' work opportunities on the mainland, forcing many younger, working-age men and women to move off the island and further fraying their ties to the land (Canty, 1989; Hollyday; Yarbrough).

The Melrose Company subsequently worked to make it more difficult for native islanders to find alternative economic opportunities on Daufuskie. With the resorts' corporate-owned ferries now providing the bulk of transportation to and from the island (shuttling white visitors and prospective resort members to and from the island by the hour), Melrose officials moved to have all ferry service relocated from the public dock to a new, private one located on resort property. This would have severed the native islanders' last remaining sources of income outside of low-wage service jobs. For years, Black Daufuskians had sold crab cakes, sweetgrass baskets, and other homemade items to arriving tourists on the public dock. The constant stream of white guests in the years since developers arrived had, island resident Sallie Coleman told county officials, provided them with a "lifeline." If it were removed, islander Lawrence Jenkins added, "many people won't have money nor any way to make money" (Minutes, Beaufort County Council; S. Ross; Korotkin, 1990a; Caton).

31 As Canty saw it, that was the point. Beaufort County, she charged, "has a sophisticated, legally knotted noose around [Black landowners'] necks and [is] [...] lynching them financially." Canty's early activism alerted outside organizations to the crisis unfolding on Daufuskie. Within months, the Christic Institute South (a social justice legal aid and advocacy organization) sent a team of lawyers and activists to investigate conditions and later file a class-action lawsuit against the Melrose Company over the desecration and illegal removal of graves from the island's cemetery. Over the next two years, Daufuskie Island became the focus of a national civil rights campaign and unprecedented media scrutiny, culminating in a scathing report on the CBS news program 60 Minutes in 1991. Represented by Christic Institute lawyers and organizers, a group of native islanders filed a successful class-action lawsuit against the Melrose Company over its illegal removal and desecration of graves (Canty, 1989).

But after having destroyed its ecological base, enclosed the commons, and suppressed alternative means of wage earning on Daufuskie, Melrose executives were well positioned by the early 1990 s to quell dissent and negative publicity by dangling jobs before a desperately poor population. At the height of the legal conflict, Melrose refused to hire persons who were active in the lawsuit and denied the most vocal activists use of its ferries, which by then offered the only regular transportation to and from the island. Those who went to work at the resorts, and tacitly agreed not to associate with, or lend support to, activists, were under no illusion as to their place in the new plantation economy. But many felt they had no choice. Daufuskie Islander Lillian Spencer captured this dilemma: "When you got to depend on people you can't always stand up for what you really believe. And, on this island, how do you live when everything is gone? [...] No transportation, no jobs, no nothing, and here comes somebody and [he] offer[s] you a job and then [...] ask[s] you [to do] these kinds of things, who wouldn't go along with the program in order to keep their job?" (Spencer).

And then, the jobs left, too. After having sided with the developers during the cemetery lawsuit, Melrose employees expected in return a modest improvement in pay, work conditions, and evidence of opportunities for advancement within the company-in other words, a fulfilling of some of the vague promises corporate executives had 
liberally doled out during the preceding public relations battle. Instead, Melrose executives doubled down on labor practices that employees described as humiliating and redolent of the old plantation economy resort executives sought to evoke in their advertising. Employees described Melrose as "a plantation where they treat workers like they own them" (Sack). In response, workers voted in 1994 to join Local 465 of the International Union of Operating Engineers, forming the first trade union in Beaufort County's history. After two years of negotiation and demonstrations against unfair labor practices, Melrose employees secured significant wage and benefit concessions. The victory reverberated across the South and the hospitality industry. But it was short-lived. Five months after agreeing to a new contract, Melrose executives sold the company to the conglomerate Club Corporation of America, based in Dallas, Texas, which, upon assuming ownership, promptly dismissed all employees. While the resort's new ownership group was eventually forced to rehire most of the workers, it was not forced to agree to earlier wage and benefit concessions, nor recognize the union. Another wave of out-migration of working-age African Americans from the island ensued. Struggling to find workers, Melrose turned to the federal government's $\mathrm{H}-2 \mathrm{~B}$ visa program, which allowed for the use of foreign workers in industries experiencing chronic labor shortages. Starting in 1999, it brought upwards of 100 young men from Jamaica to work as servers, bartenders, and groundskeepers on 9month work visas ("Tight Labor Market").

The erosion of Melrose's labor supply mirrored the physical erosion of its shoreline. In 2006, the state's Office of Ocean and Coastal Resource Management singled out the Melrose tract as suffering the highest rates of erosion on the island (in one section, up to 11 feet per year) ("Building along Oceanfront"). This was due, in large measure, to developers', beachfront owners', and the state's relentless efforts to stabilize the shoreline and protect beachfront real estate from being washed out to sea. Fiscal interests drove local and state officials to continually double down on development, approving building permits for seaside homes in areas manifestly unsuited for residential development and acceding to resort executives' and homeowners' demands to build and refortify seawalls along the shore. This and other forms of shoreline armoring, coastal scientists note, "result in the loss of critical coastal ecosystem services such as provision of nursery habitat for commercially and recreationally valuable fish and crustaceans, filtration of nutrients and pollutants from terrestrial runoff, carbon burial, and erosion protection" (Gittman et al. 306). Such armoring destroys native habitats and provides a welcoming environment for invasive species. It makes shorelines less capable of adapting to sea level rise, and coastal zones and inland areas more prone to catastrophic destruction during storms (Dugan et al. 2017).

Such are the conditions along the receding shoreline of the abandoned Melrose Resort today, where the ocean's relentless advance has served to hasten capital's retreat. In 2008, the owners of the Daufuskie Island Resort and Breathe Spa filed for bankruptcy and laid off its remaining staff. In the years that followed, a series of investors sold and resold the property, and tested out various profit-making schemes, each more dubious than the last. Eventually the sales stopped and the resort was left abandoned. Before long, native plants and wildlife came to reclaim the Jack Nicklaus-designed golf course. Following Hurricane Matthew in 2016, many of the beachfront homes built inside the gated community were destroyed and not rebuilt. 
Today, broken sewer lines and other detritus of coastal capitalism jut out from the sands of a shoreline where Black people once held baptisms and buried their dead, and which resort owners had fought for decades to make exclusive to its members and their guests. The hotel that once hosted elaborate weddings and boozy corporate retreats, and was designed to evoke an imagined antebellum past of white mastery and black servility, is now fenced off from vandals as it crumbles into an ever-encroaching sea. The original architects of this destruction, and the wealth they extracted from the land and its people, long ago vanished into the ether of global finance and investment. Capitalism takes, and then capitalism leaves. The people of Daufuskie-the few native islanders who remain and the many more who claim it as their ancestral home-are left with its discarded remains.

\section{BIBLIOGRAPHY}

ANDERSON, Jack. “An Island Time Has Forgotten.” The Washington Post, 25 December 1978.

ARCHER, Jack H., Donald L. CONNERS, Kenneth LAURENCE, Sarah Chapin COLUMBIA, and Robert BOWEN. The Public Trust Doctrine and the Management of America's Coasts. Amherst: University of Massachusetts Press, 1994.

ATUAHENE, Bernadette. “'Our Taxes Are Too Damn High': Institutional Racism, Property Tax Assessments, and the Fair Housing Act." Northwestern University Law Review, vol. 112, no. 6, 2018, p. 1501-1564.

BAGSTAD, Kenneth J., Kevin STAPLETON, and John R. D'AGOSTINO. “Taxes, Subsidies, and Insurance as Drivers of United States Coastal Development." Ecological Economics, no. 63, 2007, p. 285-298.

BROOKS, Joseph. "The Emergency Land Fund: A Rural Land Retention and Development Model." The Black Rural Landowner-Endangered Species: Social, Political, and Economic Implications. Eds. Leo McGee and Robert L. Boone. Westport: Greenwood Press, 1979, p. 117-134.

BROWER, David J., William DREYFOOS, and Don MESERVE. Access to the Nation's Beaches: Legal and Planning Perspectives. Raleigh: UNC Sea Grant, North Carolina State University, 1978.

"Building along Oceanfront Brings Risk, Responsibility." McClatchy-Tribune Business News, 27 July 2007.

CANTY, Henrietta. “Property Assessments Exorbitant, Absurd.” Island Packet, 25 November 1988.

CANTY, Henrietta. "The Real Daufuskie Island." 1989. Southern Justice Institute Records, box 31, folder Daufuskie: History and General Articles. Southern Historical Collection, University of North Carolina, Chapel Hill.

CASS, Julia. “An Unspoiled Oasis Braces for Resort.” The Philadelphia Inquirer, 9 April 1985.

CATON W.A., Jr. "A Fight between Old and New, Rich and Poor." Savannah Morning News, 28 October 1990. Southern Justice Institute Records, box 28, folder [unnamed]. Southern Historical Collection. 
CERUTI, James. "Sea Islands: Adventuring along the South's Surprising Coast.” National Geographic, 1971.

DANIELSON, Michael N. Profits and Politics in Paradise: The Development of Hilton Head Island. Columbia: University of South Carolina Press, 1995.

DEAN, Cornelia. Against the Tide: The Battle for America's Beaches. New York: Columbia University Press, 1999.

“Developers Sued for Desecrating Black Cemetery.” The People's Advocate, October 1990.

DOUGHERTY, Steve. "Daufuskie Island: Barrier Islanders Fear They Cannot Block Progress." Atlanta Constitution, 1 August 1982.

DUGAN, Jenifer E., Kyle A. EMERY, Merryl ALBER, Clark R. ALEXANDER, James E. BYERS, AlyssaLois M. GEHMAN, Natalie MCLENAGHAN, and Sarah E. SOJKA. "Generalizing Ecological Effects of Shoreline Armoring Across Soft Sediment Environments." Estuaries and Coasts, no. 41, 2017, p. 180-196.

FAULKENBERRY, Lisa V., John M. COGGESHALL, Kenneth BACKMAN, and Sheila BACKMAN. “A Culture of Servitude: The Impact of Tourism and Development on South Carolina's Coast." Human Organization, vol. 59, no. 1, 2000, p. 86-95.

FONER, Eric. Nothing but Freedom: Emancipation and Its Legacy. Baton Rouge: Louisiana State University Press, 1983.

FORSTATER, Mathew. "Taxation and Primitive Accumulation: The Case of Colonial Africa." Research in Political Economy, no. 22, 2005, p. 51-65.

GARDNER, Leigh. Taxing Colonial Africa: The Political Economy of British Imperialism. New York: Oxford University Press, 2012.

GITTMAN, Rachel K., F. Joel FODRIE, Alyssa M. POPOWICH, Danielle A. KELLER, John F. BRUNO, Carolyn A. CURRIN, Charles H. PETERSON, and Michael F. PIEHLER. "Engineering Away Our Natural Defenses: An Analysis of Shoreline Hardening in the US." Frontiers in Ecology, vol. 13, no. 6, 2015, p. 301-307.

GRABBATIN, Brian. “'The Land Is Our Family and the Water Is Our Bloodline': The Dispossession and Preservation of Heirs' Property in the Gullah-Geechee Communities of Lowcountry South Carolina." PhD diss., University of Kentucky, 2016.

HANSEN, Gunnar. Islands at the Edge of Time: A Journey to America's Barrier Islands. Washington: Island Press, 1993.

HARGROVE, Melissa Denise. "Reinventing the Plantation: Gated Communities as Spatial Segregation in the Gullah Sea Islands.” PhD diss., University of Tennessee, 2005.

HICKMOTT, Alec Fazackerley. "Black Land, Black Capital: Rural Development in the Shadows of the Sunbelt South, 1969-1976." Journal of African American History, no. 101, 2016, p. 504-534.

HOLLYDAY, Joyce. “A Plague in Paradise: Development Endangers a Way of Life on South Carolina's Daufuskie.” Sojourners, no. 21, 1992, p. 12-18.

KAHRL, Andrew W. "The Sunbelt's Sandy Foundation: Coastal Development and the Making of the Modern South." Southern Cultures, vol. 20, no. 3, 2014, p. 24-42.

KAHRL, Andrew W. The Land Was Ours: How Black Beaches Became White Wealth in the Coastal South. Chapel Hill: University of North Carolina Press, 2016. 
KAUFMAN, Wallace, and Orrin PILKEY. The Beaches Are Moving: The Drowning of America's Shoreline. New York: Doubleday, 1979.

KNOWLES, Scott Gabriel, and Howard C. KUNREUTHER. "Troubled Waters: The National Flood Insurance Program in Historical Perspective." Journal of Policy History, vol. 26, no. 3, 2014, p. 327-353.

KOROTKIN, Gayle. “To Tai [No Last Name].” 1989. Southern Justice Institute Records, box 31, folder Daufuskie: Property Taxes. Southern Historical Collection, University of North Carolina, Chapel Hill.

KOROTKIN, Gayle. “To Kathy C. Fisher.” 28 February 1990. Southern Justice Institute Records, box 31, folder Correspondence. Southern Historical Collection, University of North Carolina, Chapel Hill.

KOROTKIN, Gayle. “To Lewis Pitts.” 18 March 1990. Southern Justice Institute Records, box 31, folder Correspondence. Southern Historical Collection, University of North Carolina, Chapel Hill.

KOROTKIN, Gayle. “To Henrietta Canty.” 26 April 1990. Southern Justice Institute Records, box 31, folder Correspondence. Southern Historical Collection, University of North Carolina, Chapel Hill.

LEVIN, Martin A. "Urban Politics and Political Economy: The Politics of the Property Tax." Policy Sciences, vol. 9, no. 2, 1978, p. 237-245.

MCDOMMICK, Joe. Interview by Andrew W. Kahrl. Audio, 17 April 2014.

MICHEL-KERJAN, Erwann O. "Catastrophe Economics: The National Flood Insurance Program." Journal of Economic Perspectives, vol. 24, no. 4, 2010, p. 165-186.

MILLER, H. Crane. "The Barrier Islands: A Gamble with Time and Nature.” Environment, vol. 23, no. 9,1981 , p. 6-11, 36-42.

Minutes, Beaufort County Council. Special Meeting. Beaufort County, SC: County Council, 29 June 1989. Southern Justice Institute Records, box 29, folder County Council Minutes. Southern Historical Collection, University of North Carolina, Chapel Hill.

MITCHELL, Thomas W. "From Reconstruction to Deconstruction: Undermining Black Landownership, Political Independence, and Community through Partition Sales of Tenancies in Common." Northwestern University Law Review, vol. 95, no. 2, 2001, p. 505-580.

MORRIS, Holly. “An Island's Double Standard: Black Landowners of Daufuskie, S.C., Fight to Holdon against Inequitable Taxes Little-Publicized Farm Rate given Mostly to Whites." Atlanta Journal and Constitution, 3 June 1990.

MOUTOUSSAMY-ASHE, Jeanne. Daufuskie Island: A Photographic Essay. Columbia: University of South Carolina Press, 1982.

“Opinion Split on '60 Minutes' Story about S.C.” Philadelphia Tribune, 12 April 1991.

PAUL, Diane B. The Politics of the Property Tax. Washington: Lexington Book, 1975.

PLATT, Rutherford H. “Congress and the Coast.” Environment, vol. 27, no. 6, 1985, p. 12-17, 34-40.

RICKFORD, Russell. “'We Can't Grow Food on All This Concrete': The Land Question, Agrarianism, and Black Nationalist Thought in the Late 1960s and 1970s." Journal of American History, vol. 103, no. 4, 2017, p. 956-980.

RIVERS, Faith R. “The Public Trust Debate: Implications for Heirs' Property Owners along the Gullah Coast." Southeastern Environmental Law Journal, vol. 15, no. 1, 2006, p. 147-169. 
RIVERS, Faith R. "Restoring the Bundle of Rights: Preserving Heirs' Property in Coastal South Carolina." Presented at the Property Preservation Task Force Program: Preservation and Development of Tenancy in Common Property-Societal, Real Estate and Tax Considerations, 2006. Copy in author's possession.

ROANE, J.T. "Plotting the Black Commons." Souls: A Critical Journal of Black Politics, Culture, and Society, vol. 20, no. 3, 2018, p. 239-266.

ROBINSON, Cedric J. Black Marxism: The Making of the Black Radical Tradition. Chapel Hill: University of North Carolina Press, 1983.

ROSE, Willie Lee. Rehearsal for Reconstruction: The Port Royal Experiment. Indianapolis: BobbsMerrill, 1964.

ROSS, Justin M. “Assessor Incentives and Property Assessment.” Southern Economic Journal, vol. 77, no. 3, 2011, p. 776-794.

ROSS, Sonya. "South Carolina African-American Community Threatened by Developers." The Pittsburgh Courier, 5 December 1992.

SACK, Kevin. "Union Is Losing Battle With an Island Resort: New Owner Dismissed Most Employees." The New York Times, 24 February 1997.

SARKAR, Shayak, and Josh ROSENTHAL. "Exclusionary Taxation." Harvard Civil Rights and Civil Liberties Law Review, vol. 53, no. 2, 2018, p. 619-680.

SAX, Joseph L. "The Public Trust Doctrine in Natural Resource Law: Effective Judicial Intervention." Michigan Law Review, vol. 68, no. 3, 1970, p. 471-566.

SLAUGHTER, Sabra Conway. “"The Old Ones Die and the Young Ones Leaving': The Effects of Modernization on the Community of Daufuskie Island, South Carolina." PhD diss., University of Michigan, 1985.

SMITH, Bruce M. “Plans for Daufuskie Announced.” Sumter (SC) Daily Item, 17 October 1984.

SMITH, John P. "Cultural Preservation of the Sea Island Gullahs: A Black Social Movement in the Post-Civil Rights Era.” Rural Sociology, vol. 56, no. 2, 1991, p. 284-298.

SPENCER, Lillian. “Deposition.” 10 June 1992. Southern Justice Institute Records, box 28, folder Lillian Spencer. Southern Historical Collection, University of North Carolina, Chapel Hill.

STEIN, Samuel. Capital City: Gentrification and the Real Estate State. New York: Verso, 2019.

STOLL, Steven. Ramp Hollow: The Ordeal of Appalachia. New York: Hill and Wang, 2017.

THOMAS, June Manning. "Socio-Economic Impact Study: Resort Development and the Sea Islands.” Kiawah Island, SC: Kiawah Island Development Company and Sea Island Task Force, October 1976.

THOMAS, June Manning. "Blacks on the South Carolina Sea Islands: Planning for Tourist and Land Development." PhD diss., University of Michigan, 1977.

THOMAS, June Manning. "Effects of Land Development on Black Land Ownership in the Sea Islands of South Carolina." Review of Black Political Economy, vol. 8, no. 3, 1978, p. 266-276.

“Tight Labor Market Has South Carolina Employers Scrambling to Find Workers." Savannah Morning News, 29 February 2000.

US DEPARTMENT OF AGRICULTURE, State Laws Relating to Preferential Assessment of Farmland. Washington, DC: Government Printing Office, June 1987. 
US HOUSE OF REPRESENTATIVES. “Conference Report on S. 1018, Coastal Barrier Resources Act.” Congressional Record, 1 October 1982.

US SENATE. “S. 1018, Coastal Barrier Resources Act.” Congressional Record, 2 March 1982.

WILLIAMSON, Joel. After Slavery: The Negro in South Carolina during Reconstruction, 1861-1877. Chapel Hill: University of North Carolina Press, 1965.

YARBROUGH, Brenda Camp. “Trouble on Daufuskie: Blacks Becoming 2nd-Class Citizens on Their Island?" Atlanta Journal and Constitution, 19 November 1992.

YEADON, David. "Return to Daufuskie: The Island That Time Forgot Has Suddenly Been Remembered." The Washington Post, 8 May 1988.

\section{NOTES}

1. In his essay "Plotting the Black Commons," J.T. Roane describes the intertwined processes of racial domination and ecological devastation as defining the "racial capitalocene."

2. On the foundational relationship of race-making and racialized forms of differentiation and subordination to capitalist development, see Robinson.

3. On the use of direct taxes as a mechanism for imposing market-based relations on indigenous populations and putting new commodities (such as land) into circulation, see Forstater; Gardner; and Stoll.

4. On proliferation of "plantation" resorts and its social, political, and cultural impact on the South Carolina coast, see Faulkenberry et al. 86-95; Hargrove; Thomas, 1977; Danielson.

5. On how the prevalence of heirs property ownership among African Americans who acquired land during the century following emancipation reflected their estrangement from the legal protections and procedures available to white property owners, see Kahrl, 2016 162-164, 237-241. Lacking clear title, heirs property owners were ineligible for a number of federal programs that assisted rural farmers and could not use their land as collateral in securing a loan. The expedited nature of partition sales allowed developers to acquire property at bargain prices. See Rivers, 2007. On how the courts' increased reliance on partition sales to resolve heirs property disputes both reflected and advanced an understanding of property as "merely a fungible commodity whose value should be determined by the market," see Mitchell 532-544; Hickmott 532.

6. On the National Flood Insurance Program, see Platt; Dean; Bagstad et al.; Michel-Kerjan; Knowles and Kunreuther.

7. See also Miller.

8. On local assessors' motives and means for shaping real estate markets to benefit large-scale developers and wealthier property owners, see also Paul; Levin; J.M. Ross; Atuahene; Sarkar and Rosenthal.

9. In 1989, for example, a white-owned, 75-acre tract of coastal property paid $\$ 1,252$ in property taxes. By contrast, a 35-acre, African American-owned property received a $\$ 4,206$ property tax bill (Morris).

10. In 1988 , for example, it sold a 60 -acre tract to satisfy a $\$ 1,500$ tax debt. See Korotkin, 1990 b.

11. On African American land retention programs and back-to-the-land movements in the 1970s, see Rickford; Hickmott; Brooks. 


\section{ABSTRACTS}

In the decades following World War II, real estate development proliferated along the coastlines and waterways of the US South. But while histories of the Sunbelt recognize the role of vacation and leisure-based development in the region's economic transformation in the second half of the twentieth century, the social and environmental effects of coastal development remain underexamined. This essay uses a case study of Daufuskie Island, a barrier island on the South Carolina coast, to demonstrate the ties that bound capital accumulation, racial injustice, and environmental degradation together in the making of the modern South, and to call attention to the critical role of local governments in facilitating the most predatory and unsustainable features of real estate capitalism. It shows how, in burgeoning real estate markets, local tax administrative and enforcement powers served as a form of "accumulation by dispossession" integral to the growth and expansion of capitalist land systems, dismantling of non-market modes of land use and exchange, and forced incorporation of local populations into a low-wage, seasonal economy.

Dans les décennies qui ont suivi la Seconde Guerre mondiale, l'aménagement des littoraux et des zones riveraines dans le Sud des États-Unis a connu une forte accélération. Si les études existantes ont bien identifié le rôle du tourisme et de l'économie des loisirs dans la transformation économique de la Sunbelt dans l'après-guerre, la question des effets sociaux et environnementaux de l'aménagement des littoraux demeure négligée. À travers le cas de l'île de Daufuskie, une île barrière située sur la côte de la Caroline du Sud, cet article met au jour les liens qui existent entre l'accumulation capitaliste de profits, l'injustice raciale et les dommages environnementaux - combinaison qui est à la source du Sud moderne. Ce faisant, l'article met en lumière le rôle des gouvernements locaux dans la mise en place des aspects les plus prédateurs et non-soutenables du capitalisme foncier. Il montre comment, dans des marchés immobiliers en pleine expansion, les pouvoirs locaux de taxation et de recouvrement de l'impôt peuvent devenir des outils d' "accumulation par la dépossession » qui mettent à mal les modes d'utilisation et d'échange de la terre hors du marché, et forcent l'intégration de populations locales à une économie saisonnière fondée sur des emplois mal rémunérés.

\section{INDEX}

Keywords: coastal environments, race, real estate, taxation, capitalism

Mots-clés: littoraux, race, immobilier, impôts, capitalisme

\section{AUTHOR}

\section{ANDREW W. KAHRL}

University of Virginia 